\title{
EFFICACY OF SOME IGR FOR THE CONTROL OF PEACH FRUITFLY, BACTROCERA ZONATA (SAUNDERS) (DIPTERA: TEPHRITIDAE)
}

\author{
FAHMY, A. R. ${ }^{1}$, HEBA. A.HASSAN ${ }^{2}$, AMIRA. A.K.H. NEGM ${ }^{2}$, \\ A.M.Z. MOSALLAM ${ }^{2}$, AKILA M. EI-SHAFEI ${ }^{1}$ and M.E. EI-NAGGAR ${ }^{2}$ \\ 1. Faculty of Science, Ain Shams University, Entomology Department. \\ 2. Plant Protection Research Institute, ARC, Dokki, Giza, Egypt.
}

(Manuscript received 2 September 2012)

\begin{abstract}
Peach fruit fly, Bactrocera zonata (Saunders) (Diptera: Tephritidae), has been recognized as a serious insect pest during the last decade attacking a wide range of fruits in Egypt. The potential of some insect growth regulators, Pyriproxyfen, Methoxyfenozoide and Novaluron to cause fatal hormonal disorders in immature stages, full grown larvae and 1-day old pupae, of $B$. zonata in sandy soil was studied under laboratory conditions. In addition, morphogenetic activity as larval-adult and pupal-adult intermediates of $B$. zonata resulting from IGRs treatment was recorded. Results indicated that, $\mathrm{LC}_{50}$ for full grown larvae were $0.96,11.40$ and $64.0 \mathrm{ppm}$ in case of Pyriproxyfen, Novaluron and Methoxyfenozoide, respectively. The $\mathrm{LC}_{50}$ values for 1 -day old pupae of B. zonata were 4.50 and $3200 \mathrm{ppm}$ for Pyriproxyfen and Novaluron respectively, while Methoxyfenozoide has no fatal effect on 1-day old pupae of $B$. zonata. On the other hand, the $\mathrm{EC}_{50}$ values of full grown larvae were 1.31, 16.8 and $550 \mathrm{ppm}$ for Pyriproxyfen, Methoxyfenozoide and Novaluron, respectively. The $\mathrm{EC}_{50}$ values for 1-day pupae were 2.80, 1450 and $5000 \mathrm{ppm}$, for the same compounds, respectively. The obtained results proved that, Pyriproxyfen is a promising candidate for the control of the peach fruit fly.

Key words: Bactrocera zonata - IGR - Pyriproxyfen - Novaluron - Methoxyfenozoide - controlling agent.
\end{abstract}

\section{INTRODUCTION}

Fruits considered one of the most important crops in the whole world because of its nutritional and economic importance as well as for local utilization or exportation. Pest infestation of fruit trees may seriously affect its quantitative and qualitative productivity because of infestation with scale insects, mealy bugs, mites, wood borers and fruit flies. The peach fruit fly, Bactrocera zonata (Saund.) is considered one of the most important economic pests for several kinds of fruits in temperate, tropical and subtropical countries (Younes et. al., 2009). It attacks a wide species of soft fruits, e.g. peach, apricot, guava, citrus and mango (White and ElsonHarris, 1992 and Allwood et. al., 1999). Recently, in 1993 the peach fruit fly B. zonata was recognized in Egypt causing severe damage for several hosts. 
The control measures for fruit flies adopted mainly on contact conventional insecticides which cause destructive side effects on the environment, human health, wild life and biological control agents. So, utilization of environmental-friendly compounds with minimal mammalian toxicity such as insect growth regulators (IGRs) might help to overcome problems of conventional insecticides such as resistance, residues and resurgence. IGRs interfere with insect enzymes and hormones which play important roles throughout the entire life cycle of insects such as molting, metamorphosis, yolk synthesis, dieresis, and mobilization of energy for flight (Staal, 1975).

Insect Moulting and metamorphosis are mainly controlled by two hormones, the steroid ecdysone and the sesquiterpenoid juvenile hormone (JH) (Riddiford, 1994). Ecdysone induces and coordinates molting, but the character of the molt is determined by $\mathrm{JH}$. In the presence of $\mathrm{JH}$, there is no change in form but in the absence of $\mathrm{JH}$, the ecdysone-induced Broad (BR) transcription factors which appear at the onset of metamorphosis and have been shown to play a complex role in activation and/or suppression of genes involved in the larval-pupal transformation (Karim et. al., 1993, von Kalm et al., 1994, Hodgetts et al., 1995, Crossgrove et. al., 1996, Mugat et. al., 2000, Renault et. al., 2001). In pupal- adult transformation, ecdysone in the absence of $\mathrm{JH}$ must switch off BR so that the adult-specific program of differentiation can occur (Zhou and Riddiford, 2002).

Thus, the present work was directed to evaluate certain $I_{G} R_{s}$ with different modes of action (Pyriproxyfen, juvenile hormones analoge, Methoxyfenozoide, an ecdysone agonist, and Novaluron, chitin synthesis inhibitor) as agents that might lead to fatal hormonal disorders in immature stages (prepupae and pupae) of the peach fruit fly, B. zonata, in sandy soil under laboratory conditions. Malformations resulted due to treatment with the tested compounds will also be studied.

\section{MATERIALS AND METHODS}

\section{Rearing Technique}

Full grown larvae and pupae of B. zonata used in this study were obtained from the laboratory of Plant Protection Research Institute, Dokki, Giza, reared under laboratory conditions of $25 \pm 3{ }^{\circ} \mathrm{C}$ and $60 \pm 5 \%$ R.H.

Larvae were reared on an artificial diet consisted of $500 \mathrm{ml}$ water, $3 \mathrm{gm}$ sodium benzoate, $3 \mathrm{gm}$ citric acid, $84.50 \mathrm{gm}$ sugar, $84.50 \mathrm{gm}$ brewers yeast and 330 gm wheat bran. These ingredients were carefully mixed in large plastic container. Then eggs were scattered on the surface of the diet which was placed in plastic trays 
of $20 \times 10 \times 8 \mathrm{~cm}$ and tightly covered with muslin. After that, these trays were placed in a wooden cage with sand at the bottom to allow the jumping larvae to pupate (Shehata et. al., 2006).

Adults of $B$. zonata were reared in a cage $(100 \times 30 \times 30 \mathrm{~cm})$ with wooden frames and covered from each side with metal screen. Flies were fed on sugar and fortified protein hydrolysate at ratio of 3:1, respectively. Also, water was added in a plastic bottle. The cage was supplied with plastic fruits that had many small pores (as an oviposition receptacle). These plastic fruits were filled with $3 \mathrm{ml}$ water to receive and prevent drying of the eggs.

\section{Insecticides Used}

Pyriproxyfen (Admiral 10\% SC,Sumitomo $®$ ), Methoxyfenozoide (Runner 20\% SC, Agro consult import $\AA$ ) and Novaluron (Depron $10 \%$ SC, Isagro SPA- Italy $®$ ).

\section{Procedures}

Three pesticides were tested against certain immature stages of $B$. zonata in sandy soil that was sieved by $1 \mathrm{~mm}$ sieve. One hundred $\mathrm{gm}$ of the sieved sandy soil were put in each plastic cup. Fifteen milliliters of each concentration of each compound diluted with tap water were added. Fifty full grown larvae (the $3^{\text {rd }}$ larval instar) or 1-day old pupae were confined in each cup which containing the treated soil, then covered with muslin and tightly secured with rubber bands and left under laboratory conditions till adult emergence. Seven concentrations were used for each tested compound. Three replicates for each concentration were used. Experiments using soil and water only were also carried out as untreated check. All individuals failed to completely emerged considered dead. Also, the malformed individuals were graded and counted.

\section{Statistical Analysis}

Abbott's formula was used for comparing and correcting mortalities in the treatments (Abbott, 1925). Probit analysis was used to calculate $\mathrm{LC}_{50}, \mathrm{LC}_{90}$ values and the slope of regression lines for the tested toxicants (Finney, 1971). Sun's equation was used to calculate the toxicity index (Sun, 1950). Also, the emerged adults were inspected for detecting the pseudo- juvenilizing action of the tested compounds during larval-pupal and pupal-adult transformations, the graded scoring system was used to yield $\mathrm{EC}_{50}$ values for the tested compounds (Redfern et. al, 1970).

\section{RESULTS AND DISCUSSION}

\section{A-Sub Lethal Effect of The Tested IGRs on Full Grown Larvae and 1-Day Old Pupae}

The toxicity of three IGR compounds belonging to different chemical groups and mode of actions was tested against the full grown larvae and pupae (1-day old) 
of $B$. zonata using sandy soil treatment at different concentrations (in $\mathrm{ppm}$ ) for each compound.

\section{1-Sub Lethal Effect on Full grown larvae}

Data in Table (1) and Fig.(1) show the lethal effect of the three tested compounds against full grown larvae of $B$. zonata. It is clear that Pyriproxyfen had the greatest fatal effect at both $\mathrm{LC}_{50}$ and $\mathrm{LC}_{90}$ levels followed by Novaluron and Methoxyfenozoide, respectively. This was represented by the $\mathrm{LC}_{50}$ values $(0.96,11.40$ and $64.00 \mathrm{ppm}$ ) and $\mathrm{LC}_{90}$ values $(7.00,140.00$ and 5000ppm), for the three tested compounds, respectively. The toxicity index at $\mathrm{LC}_{50}$, for the tested compounds compared to Pyriproxyfen (the standard toxicant $=100$ ) were 8.40 and 1.50 for Novaluron and Methoxyfenozoide, while at $\mathrm{LC}_{90}$, it was 5.00 and $\mathbf{0 . 1 4}$, for the two compounds compared with pyriproxfen, respectively. The above mentioned results reveal that Pyriproxyfen was the most effective compound against full grown larvae of the peach fruit fly when applied as soil treatment. In this respect Saul et. al. (1983) reported similar results, where they stated that Ceratitis capitata (Wied) adult emergence was completely inhibited when larvae were allowed to pupate on filter paper treated with methoprene, a juvenile hormone analogue ,and that soil treatment with methoprene in the field was effective in controlling this pest on peach. Mosallam (1993) also found that Pyriproxyfen was the most effective $\left(L C_{50}=0.034 p p m\right)$ among Chlorfluazuron, Fenamiphos, Fenobucarb, Fenvalerate, Imidacloprid, Oxamyl, and Pirimiphos-methyl against the full grown larvae of Ceratitis capitata in case of sandy soil treatment. The $\mathrm{LC}_{50} \mathrm{~S}$ for the tested compounds were $27.5,0.042,6.8,50 ., 33$., 2.9 , and $0.036 \mathrm{ppm}$, respectively.

Table 1. Sub lethal effect of tested IGR compounds against the $3^{\text {rd }}$ instar larvae of $B$. zonata in sandy soil under laboratory conditions.

\begin{tabular}{|c|c|c|c|c|c|}
\hline \multirow{2}{*}{ Compound } & \multirow{2}{*}{$\begin{array}{l}\mathrm{LC}_{50} \\
(\mathrm{ppm})\end{array}$} & \multirow{2}{*}{$\begin{array}{c}\mathbf{L C}_{90} \\
\text { (ppm) }\end{array}$} & \multirow{2}{*}{ Slope } & \multicolumn{2}{|c|}{ Toxicity index at } \\
\hline & & & & $\mathbf{L C}_{50}$ & $\mathrm{LC}_{90}$ \\
\hline Pyriproxyfen & 0.96 & 7.00 & 1.54 & 100 & 100 \\
\hline Novaluron & 11.40 & 140.0 & 1.20 & 8.40 & 5.00 \\
\hline Methoxyfenozoide & 64.00 & 5000 & 1.43 & 1.50 & 0.14 \\
\hline
\end{tabular}

These results might be explained by the fact that BR proteins are first induced in the epidermis when ecdysone acts in the absence of $\mathrm{JH}$ to cause pupal commitment at the onset of metamorphosis, then persist during the prepupal period (Zhou et. al., 1998, Zhou and Riddiford, 2001). Application of JH analog at this time prevents the appearance of BR and the larval- adult transformation (Zhou and Riddiford, 2002 ). 


\section{2- Effect of tested IGRs against (1-day old) pupae of B. zonata}

The fatal effect of the tested IGRs against 1-day old pupae of B. zonata in treated sandy soil is given in Table (2) and Fig. (2). With respect to $\mathrm{LC}_{50}$ values, Pyriproxyfen was the most potent compound (4.50 ppm), while Methoxyfenozide was the least one recording $\mathrm{LC}_{50}$ more than $3000 \mathrm{ppm}$ against 1-day old pupae of $B$. zonata. According to $\mathrm{LC}_{90}$ values, Pyriproxyfen also was the most effective pesticide (122.00 ppm) followed by Novaluron (6200 ppm). Regarding to the toxicity index, at $\mathrm{LC}_{50}$ and $\mathrm{LC}_{90}($ Table, 2 ) it's clear that Novaluron was about 0.14 and $1.96 \%$ as potent as Pyriproxyfen, respectively. The $3^{\text {rd }}$ compound (methoxyfenozoide) had no lethal effect on pupae of peach fruit fly at high concentrations.

Table 2. Sub lethal effect of tested IGRs on 1-day old pupa of B. zonata in sandy soil under laboratory conditions.

\begin{tabular}{|c|c|c|c|c|c|}
\hline \multirow[b]{2}{*}{ Compound } & \multirow[b]{2}{*}{$\begin{array}{l}\text { LC50 } \\
\text { (ppm) }\end{array}$} & \multirow[b]{2}{*}{$\begin{array}{l}\text { LC90 } \\
(\mathrm{ppm})\end{array}$} & \multirow[b]{2}{*}{ Slope } & \multicolumn{2}{|c|}{ Toxicity index at } \\
\hline & & & & LC50 & LC90 \\
\hline Pyriproxyfen & 4.5 & 122 & 0.95 & 100 & 100 \\
\hline Novaluron & 3200 & 6200 & 0.95 & 0.14 & 1.96 \\
\hline
\end{tabular}

These results are in agreement with the findings of (Saul and Seiferp, 1990) who found that toxicity was highest in early pupal stages of Ceratitis capitata when treated with the insect growth regulator, methoprene. Mosallam (1993) stated that Pyriproxyfen was the most efficient compound when he tested the efficiency of Chlorfluazuron, Fenamiphos, Fenobucarb, Fenvalerate, Imidacloprid, Oxamyl, and Pirimiphos-methyl against 1- old day pupae of Ceratitis capitata recording $\mathrm{LC}_{50}$ and $\mathrm{LC}_{90}$ values of 0.137 and $1.900 \mathrm{ppm}$.

\section{B- Morphogenetic Activity of Pyriproxyfen, Novaluron and Methoxyfenozoide on Full Grown Larvae and 1-Day Old Pupae of B.zonata.}

Sandy soil was treated with the tested IGRs at different concentrations. Full grown larvae or 1- day old pupae were introduced to the above mentioned treated soils. The malformed individuals were recorded and scored according to the graduated scoring system (Tables, $3 \& 4$ and Plates A- N).

Data presented in Table 5 and Figs. 3\&4 show that Pyriproxyfen exhibited the highest effect on full grown larvae followed descendingly by Novaluron and Methoxyfenozoide. The $\mathrm{EC}_{50}$ values of the tested compounds in treated sandy soil were $1.31,16.80$ and 550 ppm, respectively. On the other hand, $E_{50}$ values of IGRs tested compounds against 1-day old pupae were 2.80, 1450 and >5000 ppm, respectively. 
Table 3. Scoring of larval-adult transformations of B. zonata after sandy soil application of the tested IGRs to full grown larvae.

\begin{tabular}{|c|c|c|c|c|}
\hline Scores & Characteristics & Pyriproxyfen & Novaluron & Methoxyfenozoide \\
\hline $\mathbf{0}$ & Adults seemed to be normal & + & + & + \\
\hline $\mathbf{1}$ & Adults with wings slightly curled & + & - & - \\
\hline $\mathbf{2}$ & Adults wingless & + & + & + \\
\hline $\mathbf{3}$ & Adults severely curled & + & - & + \\
\hline $\mathbf{4}$ & Adults attached with puprium & + & + & + \\
\hline $\mathbf{5}$ & Partial emergence(head and thorax) & + & + & + \\
\hline $\mathbf{6}$ & Partial emergence with head only & + & + & + \\
\hline $\mathbf{7}$ & Posterierly partial emergence (End only) & + & + & + \\
\hline $\mathbf{8}$ & dead pupa & + & + & + \\
\hline $\mathbf{9}$ & Larval pupal intermediate & + & + & + \\
\hline $\mathbf{1 0}$ & & + & + & + \\
\hline
\end{tabular}

Table 4. Scoring of pupal-adult transformations of B. zonata after treatment with Pyriproxyfen, Novaluron and Methoxyfenozoide to 1-day old pupae.

\begin{tabular}{|c|c|c|c|c|}
\hline Scores & Characteristics & Pyriproxyf & Novaluro & Methoxyfenozo \\
en & $\mathbf{n}$ & ide \\
\hline $\mathbf{0}$ & Adults seemed to be normal & + & + & + \\
\hline $\mathbf{1}$ & Adults with wings slightly curled & - & - & + \\
\hline $\mathbf{2}$ & Adults wingless & + & - & + \\
\hline $\mathbf{3}$ & Adults severely curled & + & - & - \\
\hline $\mathbf{4}$ & Adults attached with puprium & + & + & + \\
\hline $\mathbf{5}$ & Partial emergence(head and thorax) & + & + & + \\
\hline $\mathbf{6}$ & Partial emergence with head only & + & + & + \\
\hline $\mathbf{7}$ & Posterierly partial emergence (End only) & + & + & + \\
\hline $\mathbf{8}$ & & + & + & + \\
\hline
\end{tabular}


Table 5. EC50s values of Pyriproxyfen, Novaluron and Methoxyfenozoide against full grown larvae and 1-day old pupa of B. zonata.

\begin{tabular}{|c|c|c|}
\hline \multirow{2}{*}{ Compound } & \multicolumn{2}{|c|}{ EC $_{\mathbf{5 0}}$} \\
\cline { 2 - 3 } & Full grown larvae & Pupae \\
\hline Pyriproxyfen & 1.31 & 2.80 \\
\hline Novaluron & 16.80 & 1450 \\
\hline Methoxyfenozoide & 550 & $>5000$ \\
\hline
\end{tabular}

These results are agree with those obtained by Mosallam. (1993) studied the morphogenetic activity of Pyriproxyfen against Ceratitis capitata when applied as soil treatment and found that Pyriproxyfen had a pseudo-juvenilizing action. Also, Khalil et. al. (2010). stated that Pyriproxyfen induced high percentage of abnormalities in the adult flies of housefly Musca domestica (small size body and curved legs, crumbled wings and curved abdomen). Larval-pupal and pupal-adult intermediates were recorded.

$\mathrm{JH}$ was reported to disrupt metamorphosis of the nervous and muscular systems of Drosophila melanogaster when applied during the pre-pupal period (Restifo and Wilson, 1998).

Also the other authors stated that $\mathrm{JH}$ analogs prevent normal adult development of the abdominal integument when given at pupation (Riddiford, 1993 and Zhou and Riddiford, 2002). In addition, Zhou and Riddiford, 2002 stated that $\mathrm{JH}$ mimic causes re-expression of mRNAs for BR and a pupal cuticle protein Edg78E and suppression of mRNA for the adult cuticle protein Acp65A in the Drosophila abdomen during adult development.

In conclusion, the obtained results indicate that Pyriproxyfen achieved the highest activity against immature stages of peach fruit fly followed by Novaluron and Methoxyfenozoide. Thus, it's recommended the application of Pyriproxyfen as a promising candidate in soil treatment to control full grown larvae, pupae, and emerging adults of $B$. zonata to prevent further spread. 

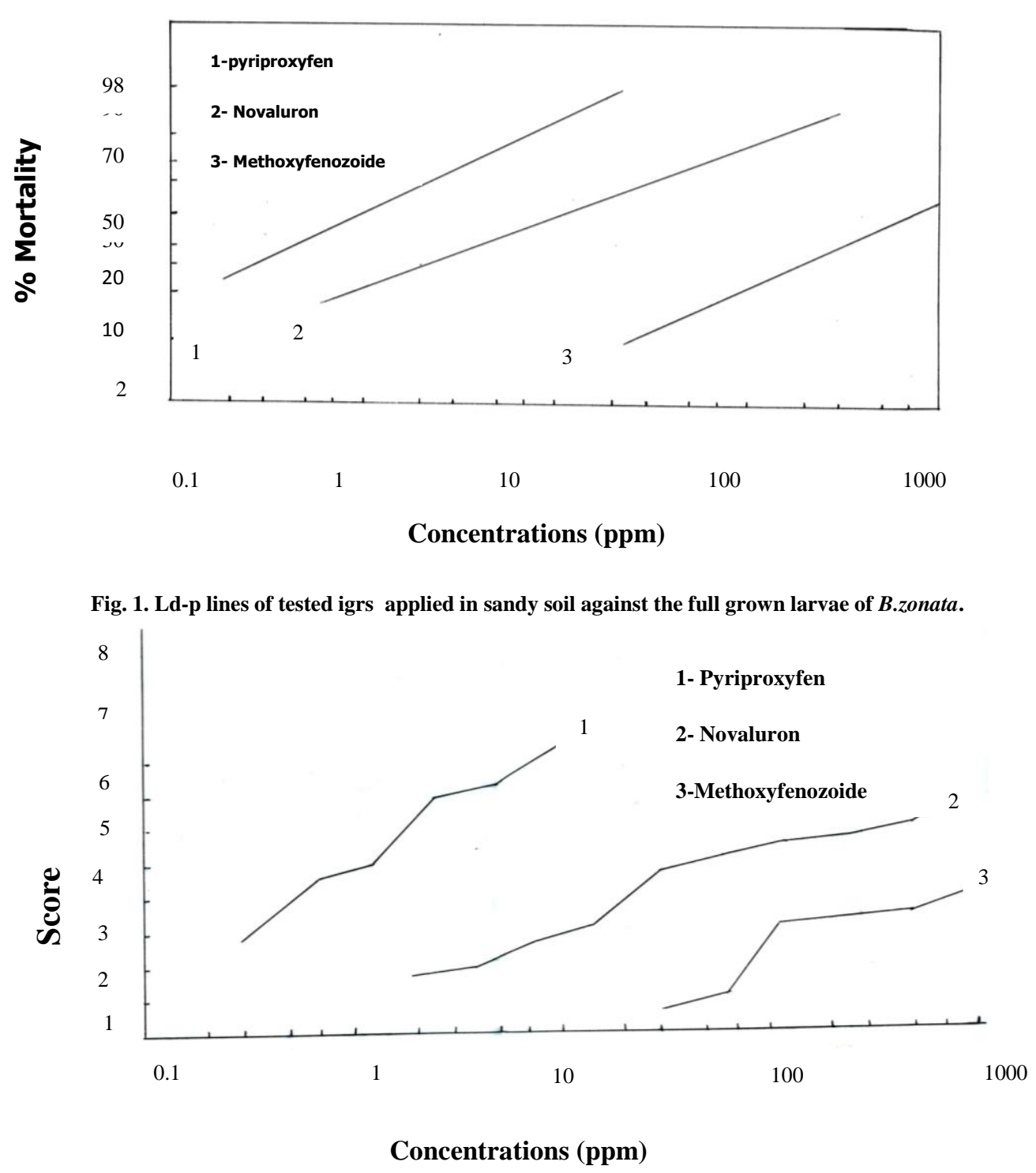

Fig. 3. Morphogenetic action of tested igrs applied in sandy soil against full grown larvae of B.zonata.

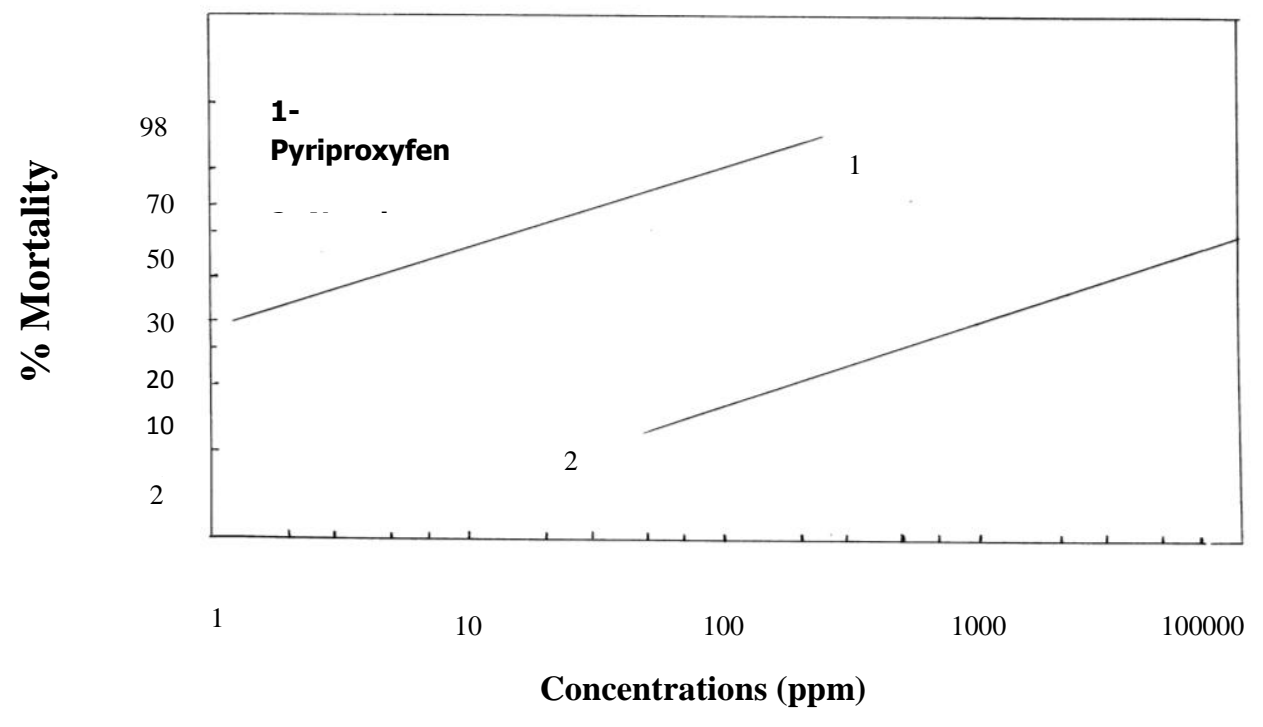

Fig. 2. Ld-p lines of tested igrs applied in sandy soil against the 1-day- old pupae of B.zonata.

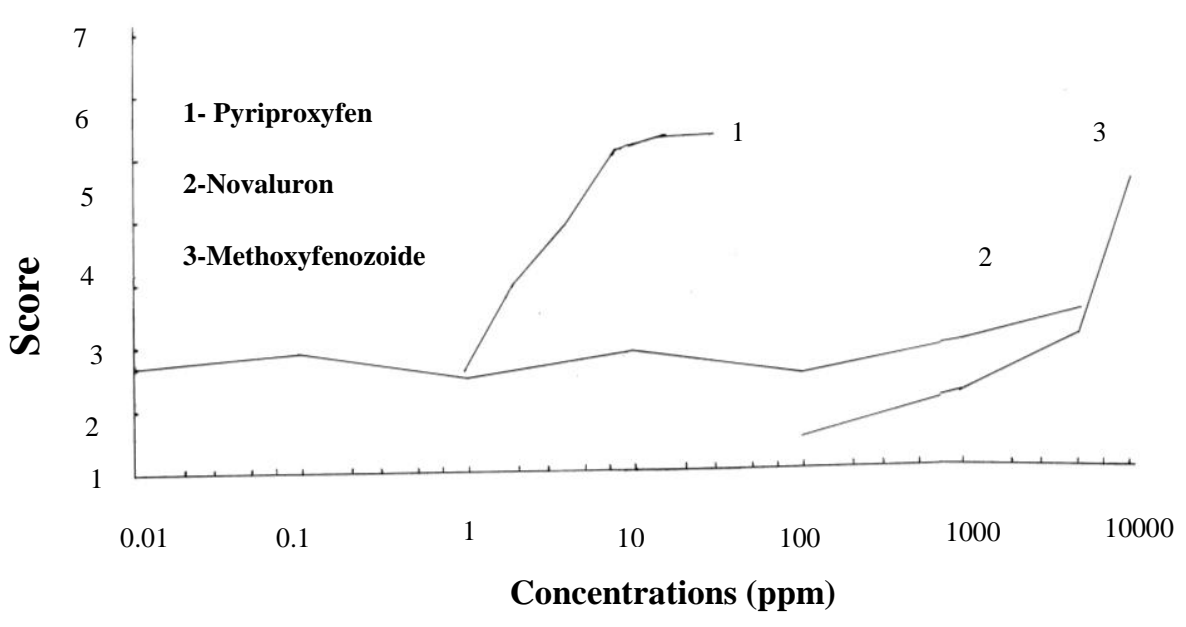

Fig. 4. Morphogenetic action of used igrs in treated sandy soil against 1-day-old pupae of B.zonata 


\section{REFERENCES}

1. Abbott, W.S. 1925. A method of computing the effectiveness of an insecticide. J. Econ. Entomol. 18 (2): 265- 267.

2. Allwood, A.L., A. Chinajariyawong, R.A.I. Drew, E.L. Hamacek, D.L. Hancock, C. Hengsawad, J.C. Ji-panin, M. Jirasurat, C. Kong Krong, S. Krit-saneepaiboon, C.T.S. Leong, and S. Vijaysegaran 1999. Host plant records for fruit flies (Diptera: Tephritidae) in Southeast Asia. Raffles Bulletin of Zoology, Supplement.

3. Crossgrove, K., C. A. Bayer, J. W. Fristrom and G. M. Guild. 1996. The Drosophila Broad-Complex early gene directly regulates late gene transcription during the ecdysone-induced puffing cascade. Dev. Biol. 180, 745-758.

4. Finney. d. j. 1971. Probit analysis a statistical treatment of the sigmoid response curve. Cambridge Univ. Press, Cambridge: pp 333.

5. Hodgetts, R. B., W. C. Clark , S. L. O'Keefe, , M. Schouls, K. Crossgrove, G. M. Guild and L. von Kalm. 1995. Hormonal induction of Dopa decarboxylase in the epidermis of Drosophila is mediated by the Broad-Complex. Development 121, 3913-3922.

6. Karim, F. D., G. M. Guild and C. S. Thummel. 1993. The Drosophila BroadComplex plays a key role in controlling ecdysone-regulated gene expression at the onset of metamorphosis. Development 118, 977-988.

7. Khalil, M.S., A.A. Assar, M.M. Abo El Mahasen and S.H. Mahmoud. 2010. Morphological effects of some insect growth regulators on Musca domestica (Diptera, Muscidae). Egypt. Acad. J. Biol. Sci., 2 (2): 29- 36.

8. Mosallam, A.M.Z. 1993. Studies on the Mediterranean fruit fly, Ceratitis capitata (Wied) and its control. M. Sc. Thesis, Fac. of Agric., Zagazig Univ. : pp 187.

9. Mugat, B., , V. Brodu, J. Kejzlarova-Lepesant, , C. Antoniewski, C. A. Bayer, J. W. Fristrom and J.-A. Lepesant. 2000. Dynamic expression of Broad-Complex isoforms mediates temporal control of an ecdysteroid target gene at the onset of Drosophila metamorphosis. Dev. Biol. 227, 104-117.

10. Redfern, R.E., T.P. Mcgovern and M. Beroza. 1970. Juvenile hormone activity of sesame and related compounds in tests on the yellow mealworm. J. Econ. Entomol., 63 (2): 540- 545.

11. Renault, N., K. King-Jones and M. Lehmann. 2001. Downregulation of the tissue-specific transcription factor Fork head by Broad-Complex mediates a stagespecific hormone response. Development 128, 3729-3737.

12. Restifo, L. L. and T. G. Wilson. 1998. A juvenile hormone agonist reveals distinct developmental pathways mediated by ecdysone-inducible Broad Complex transcription factors. Dev. Genet. 22, 141-159.

13. Riddiford, L. M. 1993. Hormones and Drosophila development. In The Development of Drosophila (ed. M. Bate and A. Martinez-Arias), pp. 899-939. Plainview: Cold Spring Harbor Laboratory Press. 
14. Riddiford, L. M. 1994. Cellular and molecular actions of juvenile hormone. I. General considerations and premetamorphic actions. Adv. Insect Physiol. 24, 213274.

15. Shehata, N.F., M.W.F. Younes and Y.A. Mahmoud. 2006. Anatomical effects of gamma irradiation on the peach fruit fly, Bactrocera zonata (Saund.) male gonads. J. Appl. Sci. Res., 2 (8): 510- 513.

16. Saul, S. and J. Seiferp. 1990. Methoprene on papay as persistence and toxicity to different developmental stages of fruit flies (Diptera, Tephritidae). J. Econ. Entomol., 83(3): 901-904.

17. Saul, S. H., R. F. L. Mau, R. M. Kobayashi, D. M. Tsuda and M. S. Nishina. 1983. Laboratory and field trails of soil applications of methoprene and other insecticides for control of the Mediterranean fruit fly (Diptera: Tephritidae). J of Econ. Entomol 76(1):174-177.

18. Staal, G.B. 1975. Insect growth regulators with juvenile hormone activity. Ann. Rev. Entomol., 20: 417- 460

19. Sun, Y.P. 1950. Toxicity index- An improved method of comparing the relative toxicity of insecticides. J. Econ. Entomol., 43 (1): 45- 53.

20. Von Kalm, L., K. Crossgrove, D. Von Seggeern, G. M. Guild and S. K. Beckendorf. 1994. The Broad-Complex directly controls a tissuespecific response to the steroid hormone ecdysone at the onset of Drosophila metamorphosis. EMBO J. 13, 3505-3516.

21. White, I.M. and M.M. Elson-Harris (1992). Fruit flies of economic significance: their identification and bionomics. CAB International, Wallingford (GB): pp 601.

22. Younes, M. W. F., N. F. Shehata and Y.A. Mahmoud. 2009. Histopathological effects of Gamma Irradiation on the peach fruit fly, Bactrocera zonata (Saund.), female gonads. J. Appl. Sci. Res., 5(3): 305-310.

23. Zhou, B. and L. M. Riddiford. 2001. Hormonal regulation and patterning of the Broad-Complex in the epidermis and wing discs of the tobacco hornworm, Manduca sexta. Dev. Biol. 231, 125-137.

24. Zhou, B., K. Hiruma, T. Shinoda and L. M. Riddiford. 1998. Juvenile hormone prevents ecdysteroid-induced expression of Broad Complex RNAs in the epidermis of the tobacco hornworm, Manduca sexta. Dev. Biol. 203, 233-244.

25. Zhou, X. and L. M. Riddiford. 2002. Broad specifies pupal development and mediates the 'status quo' action of juvenile hormone on the pupal-adult transformation in Drosophila and Manduca. Development, 129: 2259-2269. 


\section{كفلوة بعض منظمات النمو الحشرية لمكافحة ذبابة ثمار الخوخ باكتروسيرا}

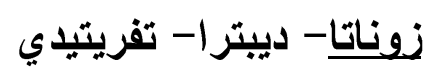

عادل رمزي فهمي1

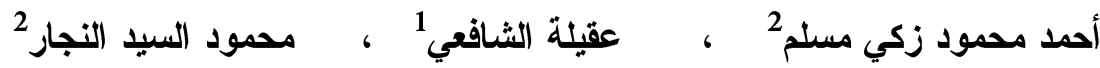

$$
\text { r. . . قسم علم الحشرات- كلية العلوم- جامعة عبن شعس. }
$$

تعتبر ذبابة الخوخ من أكثر الآفات اضرار ا بمحاصيل الفاكهة في كثير من بلدان العالم منها جمهورية مصر العربية حيث تصيب العديد من العوائل من أثجار الفاكهة. وقد اختبرت فعالية بعض منظمات النمو الحشرية.

ضد العمر اليرقي الأخير وعذارى (Novaluron ، Pyriproxyfen, Methoxyfenozoide)

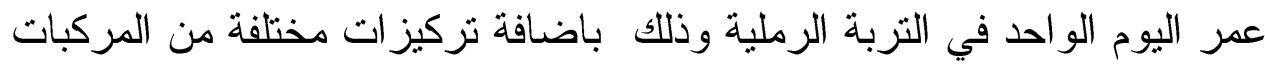

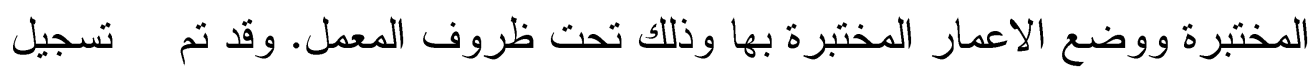
التركيز النصفي الميت لكل من الأطوار المختبرة كما سجلت التشوهات

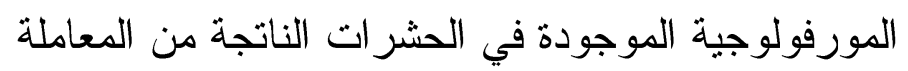
وقد أثبتت الدراسة أن مركب البيروبروكسفين كان أكثر المركبات فعالية حيث كانت قيم التركيز المميت للنصف لها 0.96 جزء في المليون للعمر اليرقي الأخير و4.50 جزء في المليون لعذارى عمر اليوم الواحد.

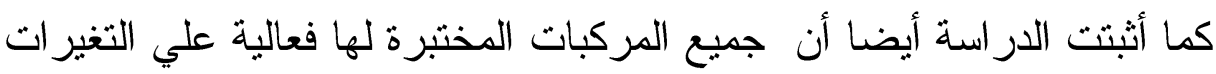

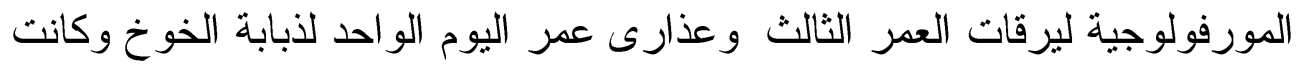

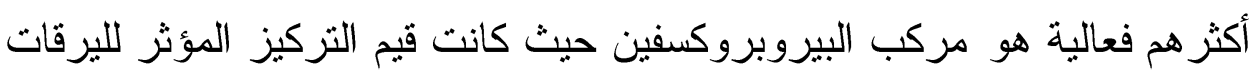
و العذارى هو 1.31و 2.8 جزء في المليون علي الترتيب.

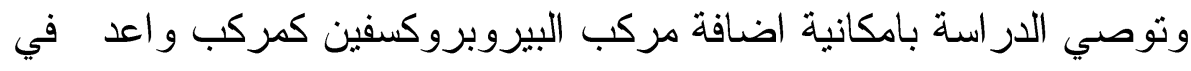
بر امج مكافحة ذبابة الخوخ. 